\title{
Effect Of Interval Exercise Versus Continuous Exercise On Increases Energy Expenditure On A Treadmill
}

\author{
Cakra Waritsu ${ }^{1}$, Dwikora Novembri Utomo ${ }^{2}$, Gadis Meinar Sari ${ }^{13 *}$ \\ ${ }^{I}$ Sport Health Science, Faculty of Medicine Universitas Airlangga, Surabaya, Indonesia \\ ${ }^{2}$ Physical Medicine and Rehabilitation Department, Faculty of Medicine Universitas Airlangga/Dr. Soetomo \\ General Hospital, Surabaya, Indonesia \\ ${ }^{3}$ Department of Physiology, Faculty of Medicine Universitas Airlangga, Surabaya, Indonesia \\ * gadis-m-s@fk.unair.ac.id
}

\begin{abstract}
Obesity is a condition of abnormal fat accumulation in adipose tissue. The cause of obesity is multi-factorial, but a common factor that contributes to weight gain is an imbalance between energy intake and energy expenditure. Doing exercise is considered as one of the most effective and efficient methods in preventing the increasing prevalence of obesity. This is because the exercise causes an increase in energy expenditure. This study aims to analyze the effect of interval exercise versus continuous exercise on increasing energy expenditure on a treadmill. This study is a pre-experiment with a posttest-only design research design using 16 obese women aged 19-23 years old, body mass index (BMI) 25$35 \mathrm{~kg} / \mathrm{m}^{2}$, percentage body fat (PBF) above $30 \%$ and fasting blood glucose (FBG) below $100 \mathrm{mg} / \mathrm{dL}$, normal hemoglobin $(\mathrm{Hb})$, normal systolic and diastolic blood pressure, normal resting heart rate, $\mathrm{VO} 2_{\max } 25-30 \mathrm{~mL} / \mathrm{kg} / \mathrm{min}$ and randomly divided into two groups, namely IE ( $\mathrm{n}=8$, interval exercise) and $\mathrm{CE}(\mathrm{n}=8$, continuous exercise). Interval exercise and continuous exercise interventions were carried out at 08.00 a.m. for 40-45 minutes using a treadmill. The measurement of energy expenditure was using OMRON Caloriscan HJA-306-EW. Data analysis techniques used the Independent-Samples T Test with the Statistical Package for Social Science (SPSS). The results obtained mean energy expenditure on IE $(251.750 \pm 19.775) \mathrm{kcal}$ and CE $(278.750 \pm 23.334) \mathrm{kcal}(\mathrm{p}=0.026)$. Based on the results of the study concluded that continuous exercise increases energy expenditure compared to interval exercise in obese women.
\end{abstract}

Keyword : Interval Exercise, Continuous Exercise, Energy Expenditure, Obese Women 


\section{STRADA Jurnal Ilmiah Kesehatan}

DOI: $10.30994 /$ sjik.v9i2.314

ISSN: 2252-3847 (print); 2614-350X (online)

Vol.9 No.2 November 2020 Page.399-404

\section{BACKGROUND}

Obesity is a multi-factorial disease that develops due to a long-term imbalance between energy intake and energy expenditure (Rambhojan et al., 2015), thus causing an increase in abnormal fat accumulation in adipose tissue (Sofa, 2018). Obesity is a very serious threat to health in the world (Marie et al., 2014; Peterson et al., 2014) with a prevalence rate that continues to increase from year to year (Chooi et al., 2019). According to the World Health Organization (WHO) (2015) obesity became a global epidemic with the prevalence of being overweight and obesity estimated at $39 \%$ of the world's population. In 1980 and 2013 showed that the prevalence of obesity in men and women showed an increase, from $28.8 \%$ up to $36.9 \%$ in men, while in women showed an increase from $29.8 \%$ to $38.0 \%$ ( $\mathrm{Ng}$ et al., 2014). The increasing prevalence of obesity requires special efforts in overcoming the problem of obesity (Carneiro et al., 2016).

Obesity is a global health problem that must be considered because obesity increases the risk of various chronic diseases such as type-2 diabetes mellitus (T2DM), hypertension and cardiovascular disease (CVD) (Gadde et al., 2018). In addition, obesity also causes dyslipidemia, arterial hypertension, ischemic heart disease, non-alcoholic fatty liver disease and several types of cancer (Moreno-Navarrete and Fernandez-Real, 2019). The causes of obesity are multi-factorial including lifestyle changes such as consumption of high alcoholic drinks, smoking habits and consumption of high-fat foods and lack of physical activity (Azkia and Wahyono, 2018). However, a common factor that contributes to weight gain is an imbalance between energy intake and energy expenditure (Norheim et al., 2014; Delany et al., 2013). Lifestyle modification is recommended to be one of the foundations to manage obesity (Gadde et al., 2018). Controlling energy intake and energy expenditure is one of the main mechanisms in regulating energy balance (Gadde et al., 2018).

The relation between energy expenditure and obesity has been studied for years, but the mechanism of energy expenditure still remains unclear (Delany et al., 2013). Energy expenditure is one of the basic components of energy balance that can help develop strategies to reduce obesity (Hill et al., 2012). Energy expenditure is considered as an energy production process from energy substrates (carbohydrates, lipids, proteins) and alcohol), where there is oxygen consumption $\left(\mathrm{O}_{2}\right)$ and carbon dioxide $\left(\mathrm{CO}_{2}\right)$ production (Volp et al., 2011). Individuals with obesity have lower energy expenditure levels compared to people who are not getting obese (normal and overweight). This kind of thing in the long run will contribute to weight gain (Carneiro et al., 2016). According to Taylor et al. (2018) explained that exercise is the right strategy in increasing energy expenditure (Hill et al., 2012). Research conducted by Grieve (2018) concluded that aerobic continuous, high intensity interval training, strength endurance, traditional resistance and high intensity resistance increase energy expenditure. According to Schaun et al. (2018) explained that continuous training has higher energy expenditure than high intensity interval training. Jung et al. (2019) explain that interval exercise and continuous exercise are appropriate recommendations for weight loss. Continuous exercise is an alternative on increasing fat distribution in overweight/obesity (Keating et al., 2014). However, the increase in energy expenditure with interval exercise and continuous exercise in obese women is still unclear. Based on the background above, the purpose of this study aims to analyze the effect of interval exercise with continuous exercise on increasing energy expenditure on the treadmill. 


\section{STRADA Jurnal Ilmiah Kesehatan}

DOI: $10.30994 /$ sjik.v9i2.314

ISSN: 2252-3847 (print); 2614-350X (online)

Vol.9 No.2 November 2020 Page.399-404

\section{METHOD}

This study is a pre-experiment with a posttest-only design research design using 16 obese women aged 19-23 years old, body mass index (BMI) $25-35 \mathrm{~kg} / \mathrm{m}^{2}$, percentage body fat (PBF) above 30\% and fasting blood glucose (FBG) below $100 \mathrm{mg} / \mathrm{dL}$, normal hemoglobin $(\mathrm{Hb})$, normal systolic and diastolic blood pressure, normal resting heart rate, $\mathrm{VO} 2_{\max } 25-35$ $\mathrm{mL} / \mathrm{kg} / \mathrm{min}$ and randomly divided into two groups, namely IE ( $\mathrm{n}=8$, interval exercise) and $\mathrm{CE}$ ( $\mathrm{n}=8$, continuous exercise). All of these research procedures were approved by the Health Research Ethics Commission of the Faculty of Medicine, Airlangga University, Surabaya number 309/EC/KEPK/FKUA/2019.

Intervention interval exercise (IE) was done by running on a treadmill with an intensity of $60-70 \%$ HRmax for 45 minutes with details of 5 minutes warming up (50-60\% HRmax), 35 minutes core (5 minutes working (60-70\% $\left.\mathrm{HR}_{\max }\right)$ ) interspersed with active recovery on the treadmill for 2.5 minutes $\left(50-60 \% \mathrm{HR}_{\max }\right)$ performed 5 repetitions) and 5 minutes of cooling (50-60\% $\mathrm{HR}_{\max }$ ). Intervention of continuous exercise (CE) was done by running on a treadmill with an intensity of $60-70 \% \mathrm{HR}_{\max }$ for 40 minutes with details of 5 minutes warming $\left(50-60 \% \mathrm{HR}_{\max }\right), 30$ minutes of the core being carried out continuously $\left(60-70 \% \mathrm{HR}_{\max }\right)$ and 5 minutes of cooling $\left(50-60 \% \mathrm{HR}_{\max }\right)$. The intervention was carried out at 08.00 a.m. using a treadmill (Richter Treadmill Semi-Commercial Evolution (4.0 hp DC)).

Height measurement (TB) was using a stadiometer (SECA, Chino, CA). Measurement of body composition consists of body weight (BMI) body mass index (BMI), percentage body fat (PBF) using TANITA (Body Composition Analyzer DC3607601 (2) -1604 FA, TANITA Corporation of America, Inc.). Blood pressure measurement was using a digital omron blood pressure monitor HEM-7130L (OMRON Model HEM-7130 L, Omron Co.). FBG measurements was using ACCU-CHEK (ACCU-CHEK ® Performance, Mannheim, Germany), while $\mathrm{Hb}$ measurements was using Easy Touch (Easy Touch GCHb, Taiwan). Energy expenditure measurement was using OMRON Caloriscan HJA-306-EW.

$\mathrm{VO} 2_{\text {max }}$ measurement was using the Astrand 6-minute cycle test method and used an ergocycle (Monark 828 E, Version 1010 Art. No: 7950-296, Vansbro, Sweden). Heart rate monitoring to control exercise intensity was using Polar (Polar H10 Heart Rate Sensor, USA, Inc.).

Data analysis techniques was using statistical packet for social science (SPSS) software version 21 (Chicago, IL, USA). The normality test uses the Shapiro-Wilk test. Data that normally distributed were tested using the Independent-Samples T Test with a significant level $(p<0.05)$. All data are displayed with mean \pm SD.

\section{RESULT}

The results of descriptive analysis of the research subject's characteristics in each group can be seen in table 1 .

Table 1. Research Subject's Characteristics

\begin{tabular}{lcccc}
\hline \multicolumn{1}{c}{ Variable } & n & IE & CE & Independent-Samples T Test \\
\cline { 3 - 4 } & & Mean \pm -SD & Mean \pm -SD & value \\
\hline Age $($ year $)$ & 8 & $21.000 \pm 1.603$ & $20.750 \pm 0.707$ & 0.693 \\
\hline Height $(\mathrm{m})$ & 8 & $1.587 \pm 0.062$ & $1.572 \pm 0.051$ & 0.863 \\
\hline Weight $(\mathrm{kg})$ & 8 & $72.637 \pm 8.364$ & $71.937 \pm 7.540$ & 0.609 \\
\hline BMI $\left(\mathrm{kg} / \mathrm{m}^{2}\right)$ & 8 & $28.825 \pm 1.758$ & $28.937 \pm 1.448$ & 0.891 \\
\hline PBF $(\%)$ & 8 & $42.800 \pm 3.584$ & $44.150 \pm 2.507$ & 0.397 \\
\hline SBP $(\mathrm{mmHg})$ & 8 & $112.500 \pm 4.629$ & $111.250 \pm 3.535$ & 0.554 \\
\hline DBP $(\mathrm{mmHg})$ & 8 & $75.000 \pm 5.345$ & $75.000 \pm 5.345$ & 1.000 \\
\hline
\end{tabular}




\section{STRADA Jurnal Ilmiah Kesehatan}

DOI: $10.30994 /$ sjik.v9i2.314

ISSN: 2252-3847 (print); 2614-350X (online)

Vol.9 No.2 November 2020 Page.399-404

\begin{tabular}{lcccc}
\hline $\mathrm{RHR}(\mathrm{bpm})$ & 8 & $81.375 \pm 14.686$ & $78.375 \pm 8.450$ & 0.624 \\
\hline $\mathrm{VO}_{2 \max }(\mathrm{ml} / \mathrm{kg} / \mathrm{min})$ & 8 & $26.195 \pm 0.968$ & $28.533 \pm 3.130$ & 0.063 \\
\hline $\mathrm{FBG}(\mathrm{mg} / \mathrm{dL})$ & 8 & $89.375 \pm 5.705$ & $89.625 \pm 7.558$ & 0.942 \\
\hline $\mathrm{Hb}(\mathrm{g} / \mathrm{dL})$ & 8 & $15.075 \pm 1.012$ & $14.525 \pm 1.030$ & 0.300 \\
\hline
\end{tabular}

Based on Table 1, the Independent-Samples $\mathrm{T}$ Test shows that there are no significant differences in the mean data characteristics of research subjects in each group. The results of the energy expenditure analysis in each group can be seen in table 2.

Table 2. Energy Expenditure Statistics Analysis Result in Each Group

\begin{tabular}{ccccc}
\hline Variable & \multirow{2}{*}{$\mathbf{n}$} & $\mathbf{I E}$ & $\mathbf{C E}$ & \begin{tabular}{c} 
Independent-Samples T Test \\
\cline { 2 - 4 }
\end{tabular} \\
\cline { 2 - 5 } -value
\end{tabular}

Based on Table 2, the Independent-Samples $\mathrm{T}$ Test shows that there is a significant difference in the average energy expenditure $(p<0.05)$.

\section{DISCUSSION}

Based on Table 2, it shows that there are significant differences in the average energy expenditure. The results showed that continuous exercise had higher average energy expenditure than exercise intervals. These results are in line with the results of a study conducted by Schaun et al. (2018) concluded that continuous training has a higher energy expenditure than high intensity interval training. This is due to differences in the type of exercise performed; interval training and continuous exercise. Interval exercise is a form of exercise that is carried out alternately between doing training activities (work intervals) with periods of low intensity activity (interrupted periods) in a training phase (Yunus, 2017), while continuous exercise is a form of exercise with speed and the distance specified, without a break until the entire distance traveled (Busyairi and Ray, 2018). Therefore, in the interval exercise there is an interrupted period in this study, namely active rest and in continuous exercise, so the work done is higher, certainly causing energy expenditure on continuous exercise to be higher. Higher work requires more energy to supply energy requirements for muscle contraction during exercise, so energy expenditure is also greater in continuous exercise.

Exercises that involve body activities require energy so that muscles can contract. The needed energy comes from food that consumed and provided from various chemical reactions in the body. The fastest energy source available for muscle contraction is adenosine triphospate (ATP). ATP is a source of energy found in muscle fibers as a source of sudden energy for muscle contraction. This potential energy has two high-energy phosphate bonds that are converted into kinetic energy. In our body, there are chemical compounds in the form of ATP. During exercise, this compound is converted to adenosine diphosphate (ADP) and produces energy for muscle contraction. The energy used for muscle contraction is called energy expenditure (Sandi, 2019). According to Jung et al. (2019) said that continuous exercise provides a positive effect with an increase in the use of fat as an energy source. The increase in fat certainly has a positive effect on the condition of obesity. Continuous exercise is also effective for weight loss. This is because with continuous exercise an increase in energy consumption can increase energy expenditure. In addition, continuous exercise also has a positive effect by increasing levels of epinephrine, norepinephrine and growth hormone in the blood, insulin secretion and cortisol. Therefore, continuous exercise in obesity is a logical alternative to improve the condition of obesity, so as to improve the health. 


\section{CONCLUSION}

Based on the results of the study, it is concluded that one continuous exercise session carried out for 40 minutes using a treadmill significantly increases energy expenditure compared to exercise intervals in obese women.

\section{REFERENCES}

Azkia, F.I., Wahyono, T.Y.M. 2018. Hubungan Pola Konsumsi Makanan Berisiko denganObesitas Sentral Pada Wanita Usia 25-65 Tahun di Bogor Tahun 20112012. JurnalEpidemiologi Kesehatan Indonesia, 2(1): 11-17.

Busyairi, B and Ray, H.R.D. 2018. Perbandingan Metode Interval Training dan ContinuousRun terhadap Peningkatan $\mathrm{VO}_{2} \max$. Jurnal Terapan Ilmu Keolahragaan, 3(1): 76-81.http://ejournal.upi.edu/index.php/JTIKOR/.

Carneiro, I.P., Elliott, S.A., Padwal, R., Bertoli, S., Battezzati, A., Prado, C.M. 2016. Is ObesityAssociated with Altered Energy Expenditure. American Society for Nutrition. AdvNutr,(7): 476-87. https://doi.org/10.3945/an.115.008755.

Chooi, Y.C., Ding, C. and Magkos, F. 2019. The epidemiology of obesity. Metabolism: Clinical and Experimental, 6-10. https://doi.org/10.1016/j.metabol.2018.09.005.

Delany, J.P. Kelley, D.E., Hames, K.C., Jakicic, J.M., Goodpaster, B.H. 2013. High EnergyExpenditure Masks Low Physical Sctivity in Obesity. International Journal ofObesity,(37): 1006-1011. https://www.researchgate.net/publication/232611079.

Gadde, K.M., Martin, C.K., Berthoud, H.R. and Heymsfield, S.B. 2018. Obesity: Pathophysiology and Management. Journal of the American College of Cardiology, 71(1): 69-84. https://doi.org/10.1016/j.jacc.2017.11.011.

Grieve, G. L. 2018. The Effects Of Exercise Mode And Intensity On Energy ExpenditureDuring And After Exercise In Resistance Trained Males. (Doctoral dissertation).Retrieved from https://scholarcommons.sc.edu/etd/4674.

Hill, J.O., Wyatt, H.R., Peters, J.C. 2012. Energy Balances and Obesity. Circulation, 126(1):126-132. https://do.org/10.1161/CIRCULATIONAHA.111.087213.

Jung, W.S., Hwang, H., Kim, J., Park, H.Y., Lim, K. 2019. Effect Of Interval ExerciseVersusContinuous Exercise On Excess Postexercise Oxygen Consumption DuringEnergy-Homogenized Exercise On A Cycle Ergometer. J Exerc Nutrition Biochem,23(2): 045-050. http://dx.doi.org/10.20463/jenb.2019.0016.

Keating, S.E., Machanm E.A., Connor, H.T.O., et al. 2014. Continuous Exercise but NotHigh Intensity Interval TrainingImproves Fat Distribution in Overweight Adults.Hindawi Publishing CorporationJournal of Obesity, 2014: 112.http://dx.doi.org/10.1155/2014/834865.

Marie, Ng., Fleming, T., Robinson, M., Thomson, B., Graetz, N., Margono, C., Mullany, E.C. Biryukov, S., Abbafati, C., Abera, S.F.et al. 2014. Global regional and national prevalence of overweight and obesity in children and adults 1980-2013: A systematic analysis. Lancet, 384(9945): 766-781. https://doi.org/10.1016/S01406736(14)60460-8.Global.

Moreno-Navarrete, J.M. and Fernandez-Real, J.M. 2019. The complement system is dysfunctional in metabolic disease: Evidences in plasma and adipose tissue from obese and insulin resistant subjects. Seminars in Cell \& Developmental Biology, 85: 164-172.https://doi.org/10.1016/j.semcdb.2017.10.025. 


\section{STRADA Jurnal Ilmiah Kesehatan}

DOI: $10.30994 /$ sjik.v9i2.314

ISSN: 2252-3847 (print); 2614-350X (online)

Vol.9 No.2 November 2020 Page.399-404

Ng, M., Fleming, T., Robinson, M., Thomson, B., Graetz, N., Margono, C., Mullany, E.C.,Biryukov, S., Abbafati, C., Abera, S.F., et al. 2014. Global, Regional, And NationalPrevalence Of Overweight And Obesity in Children and Adults During 1980-2013: aSystematic Analysis for The Global Burden of Disease Study 2013. Lancet, 384:766-781.https://doi.org/10.1016/S0140-6736(14)60460-8.

Norheim, F. Langleite, T.M., Hjorth, M., Holen, T., Kielland, A., Stadheim, H.K., Gulseth, H.L., Birkeland, K.I., Jensen, J. and Drevon, C.A. 2014. The effects of acute and chronic exercise on PGC-1 $\alpha$, irisin and browning of subcutaneous adipose tissue in humans. FEBS Journal, 281(3): 739-749. https://doi.org/10.1111/febs.12619.

Peterson, J.M., Mart, R. and Bond, C.E. 2014. Effect of obesity and exercise on the expression of the novel myokines, Myonectin and Fibronectin type III domain containing 5. PeerJ, 2: e605. https://doi.org/10.7717/peerj.605.

Rambhojan, C., Bouaziz-Amar, E., Larifla, L., Deloumeaux, J., Clepier, J., Plumasseau, J., Lacorte, J-M. and Foucan, L. 2015. Ghrelin, adipokines, metabolic factors in relation with weight status in school-children and results of a 1-year lifestyle intervention program. Nutrition \& Metabolism, 12(43): 1-10. https://doi.org/10.1186/s12986-015-0039-9.

Sandi, I.N. 2019. Sumber dan Metabolisme Energi dalam Olahraga. Jurnal PendidikanKesehatan Rekreasi, 5(2): 64-73. https://doi.org/10.5281/zenodo.3340183.

Schaun, G., Z., Pinto, S.S., Praia, A.B, D.C., Alberton, C.L. 2018. Energy expenditure andEPOC between water-based High Intensity Interval Training and Modertae IntensityContinuous Training Session in Healthy Women. Journal of Sport Sciences, 36(18):2053-2060. https://doi.org/10.1080/02640414.2018.1435967.

Sofa, I.M. 2018. Kejadian Obesitas, Obesitas Sentral, dan Kelebihan Lemak Viseral padaLansia Wanita. Amerta Nutr, 2018: 228236.https://doi.org/10.2473/amnt.v2i3.2018.228-236.

Taylor, J., Keating, S.E., Holland, D.J., Coombes, J.S., Leveritt, M.D. 2018. The ChronicEffect of Interval Training on Energy Intake:A Systematic Review and MetaAnalysis. HindawiJournal of Obesity, 2018: 113.https://doi.org/10.1155/2018/6903208.

Volp, A.C.P., Oliviera, F.C.E.D., Alves, R.D.M., Esteves, E.A., Bressan, Y.J. 2011. Energyexpenditure: components and evaluation methods. Nutr Hosp, 26(3):430440.https://doi.org/10.3305/nh.2011.26.3.5181.

World HealthOrganization(WHO). 2015. Global Status Report on Noncommunicable Diseases 2014. Switzerland: WHO

Yunus, M. 2017. Pengaruh Latihan Interval Terhadap Kenaikan Jumlah Sel Eritrosit DanVO $\mathrm{V}_{2}$ maks.

Motion, VII(1):

7989.https://www.researchgate.net/publication/330798814 